\title{
ANALISIS PENGARUH NYANYIAN JEMAAT TERHADAP KUALITAS IBADAH GEREJA PROTESTAN di INDONESIA bagian BARAT (GPIB) JEMAAT BUKIT ZAITUN MAKASSAR
}

\author{
Rohani Siahaan \\ sttjaffraymakassar@yahoo.co.id
}

\begin{abstract}
ABSTRAK
Tujuan penelitian ini adalah untuk mengetahui, sejauh mana nyanyian jemaat memengaruhi kualitas penyembahan umat dalam ibadah Gereja Protestan di Indonesia bagian Barat (GPIB) Jemaat Bukit Zaitun Makassar. Bagaimana umat menyikapi nyanyian jemaat sebagai suatu liturgi, erat hubungannya untuk meningkatkan kualitas ibadah penyembahan umat di gereja protestan tradisional seperti GPIB.

Metode penelitian kualitatif dengan studi kasus. Data dikumpulkan secara induktif melalui observasi kepada jemaat yang terdiri dari para pelayan musik (organis, kantoria, paduan suara), jemaat awam secara random untuk kemudian dianalisis.

Dari hasil penelitian menunjukkan bahwa jemaat tidak sepenuhnya tahu, kenal, dan sadar akan hakikat nyanyian dalam ibadah. Jemaat banyak tidak memahami hubungan nyanyian dengan liturgi berlandaskan muatan teologia Alkitab, dan tradisi, sehingga jemaat cenderung bersikap acuh tak acuh dalam merespon nyanyian, begitupun pada saat menyanyikannya. Perbedaan pendapat di antara jemaat tentang penggunaan istilah penyembahan yang kurang dikenal dan tidak biasa di kalangan protestan tradisional - kata penyembahan sering dimaknai sebagai sebuah ritual khusus dalam liturgi ibadah kaum kharismatik - sehingga menjadi penghambat dalam memahami nyanyian sebagai sarana penyembahan dalam liturgi.
\end{abstract}

Kata Kunci : nyanyian jemaat, kualitas, ibadah 


\section{PENDAHULUAN}

\section{Latar Belakang Masalah}

Salah satu kekayaan warisan liturgi yang menarik untuk disimak dalam ibadah gereja protestan tradisi seperti GPIB adalah nyanyian jemaat. Nyanyian jemaat yang dimiliki dan dilagukan bersama-sama, selain menjadi salah satu upaya dalam menumbuhkan semangat persekutuan gerejawi, nyanyian-nyanyian ini menggambarkan visi gereja untuk selalu hidup dan berkembang sesuai dengan perkembangan hidup jemaat. Pesan yang terkandung dalam syairnya memerdalam misteri iman akan Yesus Kristus yang dirayakan dalam ibadah, memerlukan suara hati yang terungkap secara nyata karena memungkinkan umat untuk lebih baik menangkap firman Tuhan sekaligus menopang penyerahan diri kepada Allah dan mendorongnya untuk memuliakan Tuhan.

Ungkapan yang mengatakan: "Jangan sekali-kali mengabaikan salah satu dari nyanyian tersebut, tetapi hendaklah ketiganya digunakan secara seimbang," pada mulanya menjadi prinsip pelayanan musik gereja yang masih terus dipertahankan. Sampai akhir tahun 80-an, kesetiaan dalam menggunakan nyanyian Mazmur mulai bergeser sedikit demi sedikit. Jemaat-jemaat lokal GPIB di Makassar sudah sangat jarang, bahkan dapat dikatakan hampir tidak menggunakan lagi nyanyian Mazmur dalam liturginya. Alasannya cukup sepele, katanya nyanyian Mazmur sulit dinyanyikan, tidak enak karena unmelodis. ${ }^{2}$ Gereja dan jemaat mulai meninggalkan nyanyian Mazmur 'kuno' versi buku nyanyian Mazmur dan Nyanyian Rohani. Berikutnya jemaat masih menyanyikan Mazmur tetapi Mazmur yang merupakan versi baru di mana sajak-sajaknya sudah disederhanakan. Mazmur baru ini bersama kidung pujian/himne dan nyanyian rohani, ditata ulang dalam buku nyanyian Kidung Jemaat yang diterbitkan oleh Yamuger. Nyanyian dalam Kidung Jemaat dianggap lebih praktis dan mudah digunakan, karena selain memuat ketiga bentuk nyanyian yaitu: Mazmur, Kidung Pujian, dan Nyanyian Rohani; terdapat juga nyanyian-nyanyian oleh musisi gerejawi dari Asia atau tradisi Timur, termasuk Indonesia. Nyanyian-nyanyian ini juga dianggap sudah memenuhi kaidah musik yang baik sebagai sebuah nyanyian jemaat, antara lain: mencerminkan keesaan, tata bahasa yang sederhana, lagu/melodi stabil, isi syair tidak bersifat pribadi, serta pesan lagu mudah dipahami, dan dapat dinyanyikan setelah dipelajari dalam tempo singkat.

\footnotetext{
${ }^{1}$ G. Bennett, Dasar Musik Gerejawi (Ujungpandang, STTJ), n.p.

${ }^{2}$ Parera, Wawancara penulis, Makassar, Sulawesi Selatan 23 Maret 2013.
} 
Namun sekarang pergeseran dan perubahan yang cukup signifikan terjadi lagi atas pemakaian nyanyian dalam liturgi ibadah GPIB. Bukan hanya karena kurang memakai mazmur, himne dan nyanyian rohani yang ada di Kidung Jemaat, tetapi lebih pada munculnya nyanyian-nyanyian baru yang beratmosfir musik etnik Indonesia maupun Asia pada umumnya. Nyanyian-nyanyian baru ini, isi syairnya lebih kontekstual, mencakup hampir semua aspek kehidupan umat dengan penekanan pada kebajikan hidup dan iman yang rasional. Ritme, irama, dan melodi ada yang hanya berupa adaptasi dari musik asli tradisional tetapi kebanyakan merupakan gubahan original, baik syair maupun melodi yang bersumber dari lagu etnik yang ada di seantero nusantara.

Nyanyian-nyanyian baru ini bukan hanya mampu membuat umat mengangkat hatinya ke sorga, tetapi sekaligus seakan mewakili keseluruhan wajah warga jemaat GPIB yang memang berasal dari berbagai suku yang ada di ujung barat hingga ujung timur Indonesia. Nyanyian-nyanyian baru ini begitu cepat akrab bagi jemaat, sudah diterbitkan dalam bentuk buku oleh POKJA MUGER Sinode GPIB dan menjadi nyanyian resmi jemaat dengan nama Gita Bakti dan pemakaiannya setara dengan Kidung Jemaat.

Seperti diketahui, penyelenggaraan nyanyian jemaat sebagai salah satu unsur liturgi ibadah GPIB, bentuk mazmur, himne, nyanyian rohani maupun yang bernuansa etnik, semua dipakai dalam tata ibadah yang diatur secara cermat pada empat rumpun ibadah: pertama, menghadap Tuhan; kedua, pelayanan Firman; ketiga, pemberian umat; keempat pengutusan. Setiap nyanyian yang terdapat pada rumpun bertujuan untuk mendukung, menguatkan, dan melengkapi liturgi yang berkaitan erat dengan tema ibadah maupun kalender gereja.

Setidaknya delapan hingga sembilan nyanyian proprium (nyanyian yang selalu berubah dan berbeda dinyanyikan setiap minggu, baik dalam ibadah hari minggu biasa atau pada ibadah hari-hari raya gereja yang dirangkaikan dengan sakramen perjamuan kudus atau babtisan); jumlah ini belum termasuk ordinarium (nyanyian yang bersifat tetap), seperti : doxologi, litani, haleluya, dan nyanyian berkat yang menjadi kelengkapan seluruh tatanan liturgi.

Jelaslah di sini, bahwa nyanyian jemaat adalah kekuatan yang mendukung kelangsungan sebuah liturgi ibadah. Nyanyian melibatkan partisipasi langsung seluruh umat, baik untuk nyanyian ordinarium maupun nyanyian proprium. Konsepsi partisipasi jauh lebih luas dan bermakna karena seluruh umat dengan segala keberadaannya ikut masuk dan menghayati liturgi ibadah, ${ }^{3}$ membentuk penyembahan yang

${ }^{3}$ E. Martasudjita Pr, Penyajian Musik Gereja Dalam Perayaan Liturgi Musik Gereja Zaman Sekarang (Yogyakarta: PML A-63, 2009), 49. 
sakral dan rohani, menggiring umat untuk mengalami hadirat Tuhan. Dengan demikian nyatalah, bahwa nyanyian mempunyai peran yang sangat penting dalam ibadah. Melalui nyanyian, energi dan gaya penyembahan diekspresikan dalam nuansa yang ada pada umat: kegembiraan, kekhidmatan, dan keagungan, bahkan kepedihan sekalipun; artinya, penyembahan bukan hanya dengan respon fisik (saja), yang cenderung berupa luapan emosi, disertai tepuk tangan, sorak-sorai yang riuh dengan lompatan-lompatan dan semacamnya, hal yang tidak biasa dalam ibadah liturgi di kalangan gereja protestan tradisi, tetapi hanya dengan postur atau sikap tubuh disertai suara yang ekspresif pun sudah dapat menandai umat berada di dalam hadirat Allah.

Dengan mengamati sikap umat secara langsung pada saat beribadah, mengadakan wawancara secara random atas anggota jemaat aktif, baik majelis, pemusik, penyanyi, anggota paduan suara, dan jemaat awam, penulis tertarik meneliti secara khusus tentang bagaimana sesungguhnya umat GPIB Jemaat Bukit Zaitun memahami dan menyadari, rangkaian ibadah yang disusun dalam tata liturgi adalah penyembahan yang utuh, nyanyian jemaat mendorong, mendukung, dan menguatkan sehingga hati dan pikiran umat tertuju kepada Allah. Dan untuk penulisan hasil penelitian ini, penulis memberi judul: "Analisis Pengaruh Nyanyian Jemaat Terhadap Kualitas Ibadah Di Gereja Protestan di Indonesia bagian Barat (GPIB) Jemaat Bukit Zaitun Makassar."

\section{Pokok Masalah}

Sebagaimana telah diuraikan pada latar belakang penulisan karya ilmiah, maka kajian masalah yang akan diteliti adalah:

Pertama, bagaimana nyanyian yang digunakan dalam liturgi ibadah memengaruhi kualitas penyembahan jemaat dalam ibadah GPIB Jemaat Bukit Zaitun Makassar?

Kedua, bagaimana pertumbuhan spritualitas penyembahan dengan memahami kepentingan nyanyian dalam liturgi ibadah warga GPIB Jemaat Bukit Zaitun Makassar?

Ketiga, sejauh mana hubungan pengaruh pemahaman jemaat terhadap nyanyian jemaat dapat meningkatkan kualitas penyembahan dalam ibadah GPIB Jemaat Bukit Zaitun Makassar?

\section{Tujuan Penelitian}

Berdasarkan rumusan masalah, maka tujuan yang hendak dicapai dalam penelitian ini adalah: 
Pertama, untuk mengetahui bagaimana nyanyian dalam liturgi ibadah dapat memengaruhi kualitas ibadah warga GPIB Jemaat Bukit Zaitun Makassar.

Kedua, untuk mengetahui sejauh mana pengaruh nyanyian jemaat terhadap pertumbuhan spritualitas penyembahan warga GPIB Jemaat Bukit Zaitun Makassar melalui pemahaman akan penggunaan nyanyian dalam liturgi ibadah.

Ketiga, untuk menjelaskan pengaruh pemahaman jemaat terhadap nyanyian jemaat dalam liturgi ibadah sehubungan dengan kualitas ibadah warga GPIB Jemaat Bukit Zaitun Makassar.

\section{Batasan Penelitian}

Demi efisiensi waktu dan guna memaksimalkan hasil penelitian sesuai dengan harapan, maka masalah penelitian adalah:

Pertama, berfokus hanya pada warga GPIB Jemaat Bukit Zaitun Makassar yang terdiri dari jemaat aktif, pemusik, kantoria, prokantor, majelis, dan jemaat awam.

Kedua, pada pemahaman jemaat tentang nyanyian jemaat dalam liturgi ibadah merupakan bagian dari penyembahan dalam ibadah umat.

Ketiga, nyanyian jemaat dalam liturgi ibadah menumbuhkan dan meningkatkan kualitas penyembahan dalam ibadah umat.

\section{Manfaat Penelitian}

Adapun manfaat yang diperoleh dari penulisan karya ilmiah ialah:

Pertama, aspek praktisnya membantu warga jemaat memahami kepentingan nyanyian jemaat di dalam ibadah liturgi sebagai sarana untuk menyembah.

Kedua, aspek teologisnya memberikan pemahaman kepada warga jemaat dasar alkitabiah, historikal, dan filosofi nyanyian di dalam ibadah liturgi.

Ketiga, aspek teoritisnya menjadi sumbangan bagi warga jemaat dan gereja untuk meningkatkan pelayanan musik dan nyanyian sebagai sarana penyembahan.

Keempat, aspek akademisnya sebagai salah satu syarat dalam menyelesaikan pendidikkan strata dua pada program Pascasarjana STT Jaffray Makassar.

\section{Metode Penelitian}

Metode penelitian yang dimaksud penulis yaitu:

Pertama, mengadakan penelitian langsung di lapangan. Mengamati sikap warga jemaat saat beribadah hari minggu di gereja. Kedua, melaksanakan wawancara dan kuisioner kepada responden yang terdiri 
dari majelis, pemusik, penyanyi, kantoria, prokantor, dan jemaat awam. Ketiga, pengambilan dan pengumpulan data dari buku-buku yang berkaitan dengan materi pembahasan dalam penulisan karya ilmiah sehingga dapat mencapai sasaran dan kesimpulan akhir.

\section{Nyanyian Jemaat}

\section{Pengertian Nyanyian Jemaat}

Menurut kaidah musik, nyanyian jemaat digolongkan pada community singing, ${ }^{4}$ nyanyian bersama yang dapat dilakukan secara massal, sama seperti lagu-lagu nasional, atau lagu-lagu pantun, dan lagu-lagu patriot yang dinyanyikan oleh publik di stadion saat menonton sepak bola.

Kategori nyanyian jemaat dapat dilihat dan diketahui melalui penempatan nyanyian-nyanyian pada rumpun ibadah yang terdiri dari empat bagian besar. ${ }^{5}$

Pertama, Menghadap Tuhan. Pada rumpun ini, kategori nyanyian diisi dengan nyanyian pembukaan yang mengekspresikan kesadaran jemaat sedang menghadap Tuhan, sehubungan dengan pengakuan dan pengampunan, kemudian sehubungan dengan doa permohonan dan invokasi Roh Kudus. Kedua, Pelayanan Firman. Pada rumpun ini, disajikan nyanyian tentang penciptaan, perjanjian Allah dengan umat-Nya, Penantian Mesias, Kelahiran Yesus, Hidup dan karya Yesus selaku Mesias, Masa pra Paskah, masa Sengsara dan Paskah, Kenaikan, Pentakosta, Roh Kudus dalam jemaat, gereja di dunia dan di surga, akhir zaman serta kerajaan Kristus yang kekal. Ketiga, Respon Umat. Rumpun ini disebut sebagai rumpun respon umat atau pengucapan syukur umat. Kategori nyanyian jemaat pada rumpun ini terdiri dari: pengucapan syukur, puji-pujian, pengabdian dan keesaan serta upacara khusus lainnya. Keempat, Pengutusan. Pada rumpun penutup ini nyanyian jemaat memiliki kategori dengan isi yang bermakna jemaat dihantarkan memasuki dunia perutusan dan diberkati.

\section{Kualitas Ibadah}

Pengertian Ibadah

Kamus Umum Bahasa Indonesia mendefinisikan "ibadah" berarti ibadat, berbakti, kebaktian,menjalankan agama dengan sungguhsungguh hati. ${ }^{6}$ Ibadah adalah perbuatan yang menyatakan setia dan hormat, memerhambakan diri, perbuatan baik. Bakti yang dapat

11.

${ }^{4}$ H. A. Pandopo, Menggubah Nyanyian Jemaat (Jakarta: BPK Gunung Mulia, 1984),

${ }^{5}$ H.A. van Dop, 48-49.

${ }^{6}$ Kamus Umum Bahasa Indonesia, s.v. "ibadah" 
ditujukan baik untuk seseorang, negara, maupun untuk Tuhan, yang dilakukan dengan sukarela. Rasid Rachman dalam bukunya Pembimbing ke Dalam Sejarah Liturgi, mengatakan, kata ibadah berasal dari bahasa Arab, yakni ebdu atau $a b d u(a b d i=$ hamba). Kata ini sejajar dengan kata bahasa Ibrani, abadah (ebed = hamba), yang artinya perbuatan untuk menyatakan bakti kepada Tuhan. ${ }^{7}$

Dalam bahasa Yunani, banyak dan beragam kosa kata yang mengartikan kata ibadah, antara lain: latreia, digunakan untuk menyatakan kewajiban menerapkan hidup beribadah bagi umat (Fil.3:3). Proskunein = perbuatan tunduk diri. Seperti tertulis pada Matius 4:10 menulis, "Enyahlah iblis! Sebab ada tertulis: Engkau harus menyembah (proskunseis) Tuhan Allahmu, dan hanya kepada Dia sajalah engkau berbakti (latreuseis), "maknanya, menyembah dan berbakti kepada Tuhan tidak dapat dipertukarkan dengan harta dan kuasa." Ibadah terkait seerat-eratnya dengan suatu kegiatan manusia Allah, yakni dengan pelayanan kepada Tuhan.

\section{Tujuan Ibadah}

Ibadah dapat berlangsung di mana saja dan kapan saja, bahkan dalam setiap keadaan dan situasi. Bagi setiap orang percaya, penting mengetahui dan memahami tujuan ibadah. Pada kesempatan ini, penulis hendak menunjukkan dua implikasi tujuan ibadah.

Pertama, tujuan ibadah yang berhubungan dengan Allah. Di sini diartikan tujuan ibadah mendatangkan kemuliaan bagi Allah dan melayani Allah. Jelasnya, tujuan ibadah yang utama mendatangkan kemuliaan Allah. Alkitab mengatakan bahwa Allah menciptakan dunia ini untuk kemuliaan-Nya sendiri. Bukan hanya manusia, bahkan seluruh ciptaan diciptakan hanya untuk kemuliaan-Nya. Tatanan ciptaan-Nya merupakan ungkapan kreativitas-Nya. ${ }^{9}$ Sedang tujuan ibadah untuk melayani Allah, dapat dijelaskan sebagaimana doa St. John Chrysostom pada abad ke-4 yang berbunyi: "Berkenanlah, ya Tuhan, untuk menerima pelayanan pujian ini yang kami persembahkan kepada-Mu"10 Artinya, tujuan ibadah merupakan wawasan yang sangat indah. Sebagai ciptaan Allah, ketika umat memuji maka umat benar-benar melayani Allah, Ia senang jika umat beribadah kepada-Nya, memuji-Nya, mengakui-Nya, dan bersukacita di dalam Dia.

Kedua, tujuan ibadah dipandang dari sudut yang berhubungan dengan manusia. Ibadah adalah sarana untuk menghadirkan Kristus di

\footnotetext{
${ }^{7}$ Rasid Rachman, 3.

${ }^{8}$ Ibid.

${ }^{9}$ Robert Webber, 558-559.

${ }^{10}$ Ibid.
} 
gereja. Ibadah adalah pembangunan tubuh Kristus (IKor.12-14). Suatu bagian pokok pengajaran dalam Perjanjian Baru mengenai ibadah yang berbicara tentang kesatuan sebagai tubuh Kristus, yaitu gereja. Hal ini memberi arti, masing-masing orang membawa karunianya ke gereja. Karena, tidak semua orang memiliki bakat dan talenta yang sama; namun apa pun karunianya semua mempersembahkannya untuk kehidupan gereja, mengabdikannya demi berfungsinya tubuh Kristus. ${ }^{11}$

Dari kedua implikasi di atas, jelas bahwa tujuan ibadah dapat diartikan sebagai suatu respon umat atas panggilan beribadah bagi umat Tuhan. ${ }^{12}$ Di sini terkandung kerinduan umat untuk memperoleh pengalaman bersekutu dengan sesama, berkumpul dengan orang lain untuk melangsungkan penyembahan bersama-sama. ${ }^{13}$ Karena kasih Tuhan kepada manusia, Ia telah mengorbankan dan memersembahkan diri-Nya demi keselamatan manusia. "Sebab segala sesuatu adalah dari Dia dan oleh Dia dan kepada Dia, bagi Dialah kemuliaan sampai selamalamanya" (Rom.1l:36). Tujuan ibadah hanya untuk kemuliaan Tuhan (soli deo gloria), karena itu dalam ibadah terkandung pelayanan, kesaksian, persekutuan, dan pembinaan ${ }^{14}$ (Mat.5:16b).

\section{Fungsi Nyanyian dalam Ibadah}

Menyanyi dan nyanyian adalah dua hal yang tidak dapat dipisahkan dari kehidupan orang percaya. Sebagai partisipasi langsung jemaat dalam ibadah, nyanyian jemaat mempunyai fungsi utama dalam ibadah yaitu, pengakuan = "aklamasi" dan kesaksian = "proklamasi".

Pengakuan atau aklamasi di sini, menunjuk pada pengakuan akan karya keselamatan yang dikerjakan Allah di dalam Yesus Kristus; dan kesaksian atau proklamasi menunjuk pada kesaksian orang percaya kepada orang lain (yang belum percaya) atas segala perbuatanperbuatan Tuhan terhadap manusia dan seluruh ciptaan-Nya. ${ }^{15}$

Tentang nyanyian jemaat, reformator Martin Luther mengatakan: "nyanyian jemaat harus bervariasi dan menjemaat,"16 sedangkan Johannes Calvin berkata: "untuk membuat Mazmur sebagai nyanyian jemaat maka umat harus diajak dan diajarkan menyanyikan lagu-lagu yang bernilai," dalam hal ini Calvin selalu beranggapan hanya nyanyian Mazmur yang layak menjadi nyanyian penyembahan di dalam liturgi ibadah.

\footnotetext{
${ }^{11}$ Ibid.

${ }^{12}$ Simon Chan, 43.

${ }^{13}$ Buku GPIB. Menata Ibadah (Jakarta: Penerbitan Sinode GPIB).

${ }^{14} \mathrm{Ibid}$

${ }^{15}$ J. L.Ch Abineno., Ibadah Jemaat (Jakarta: BPK Gunung Mulia, 2005), 27.

${ }^{16}$ Rachman Rasid, 169.
} 


\section{METODOLOGI PENELITIAN}

\section{Profil GPIB Jemaat Bukit Zaitun Makassar}

Gereja Protestan di Indonesia bagian Barat (GPIB) Jemaat Bukit Zaitun beralamat jalan Cendrawasih No 353 Makassar. Merupakan gereja yang memiliki jemaat terbanyak dan terbesar di antara ke-7 Jemaat GPIB yang ada di Makassar. Bahkan Sinode mencatat, dari 300an Jemaat GPIB yang tersebar di Indonesia, GPIB Jemaat Bukit Zaitun Makassar adalah Jemaat ke-3 terbesar setelah GPIB Efata dan GPIB Immanuel di Jakarta. Jumlah anggota jemaat seluruhnya hingga semester pertama tahun 2013 sebanyak 1043 kepala keluarga, terbagi atas 13 sektor pelayanan (Sekpel), dikordinir dan dilayani majelis masing-masing sektor yang jumlah keseluruhan 149 orang, terdiri dari penatua dan diaken

Pendeta yang melayani secara struktural-fungsional 3 orang, ditambah 1 vikaris. Pendeta dengan jabatan sebagai pendeta jemaat 6 orang, dengan tugas melayani ibadah mimbar dan atau sakramen maupun pelayanan bidang-bidang kategorial.

Pelayanan bidang kategorial (Pelkat) terdiri atas: pelayanan anak (PA), persekutuan teruna (PT), gerakan pemuda (GP), persatuan kaum perempuan (PKP), persekutuan kaum bapak (PKB), persekutuan kaum lanjut usia (PKLU). Pendukung pelayanan lainnya, komisi-komisi yang dibentuk sesuai bidang kebutuhan, bekerja dan bertanggung jawab kepada ketua-ketua yang disebut pelaksana harian majelis jemaat (PHMJ). Berbagai program kerja yang meliputi pembinaan warga jemaat, pelayanan dan kesaksian, gereja dan masyarakat, diakonia, pembangunan, kesehatan, dana, dan hal yang bersifat oikumenis diselenggarakan baik dalam jemaat maupun kategorial.

Tempat ibadah hari minggu, selain gedung gereja Bukit Zaitun di jalan Cendrawasih, digunakan juga gedung gereja GKSS Makio Baji di jalan Tupai dengan sistim kerjasama dan Aula Asrama Mattoangin.

\section{Metode Penelitian}

Dalam penelitian dikenal dengan sejumlah metode. Penelitian berdasarkan metode yang digunakan dapat dikelompokkan menjadi delapan kelompok, yakni: penelitian survei, ex post facto, eksperimen, naturalistik, policy research, action research, evaluasi dan sejarah. ${ }^{17}$ Variabelvariabel yang diukur dinyatakan dengan variabel bebas dan variabel

\footnotetext{
${ }^{17}$ Sugiyono, Statistika untuk Penelitian (Bandung: Alfabeta, 1999), 7. 
terikat. Hubungan antar variabel tersebut digambarkan sebagai berikut: ${ }^{18}$

Keterangan:

$\mathrm{X}$ : PENGARUH NYANYIAN JEMAAT:

$\mathrm{X}_{\mathrm{I}}$ : Menghadap Tuhan

$\mathrm{X}_{2}$ : Pelayanan Firman

$\mathrm{X}_{3}$ : Pengucapan Syukur

$\mathrm{X}_{4}$ : Pengutusan

Y: $\quad$ KUALITAS IBADAH JEMAAT

Dapat dikategorikan bahwa variabel $\mathrm{X}: \mathrm{X}_{1}, \mathrm{X}_{2}, \mathrm{X}_{3}, \mathrm{X}_{4}$, sebagai dimensi dari variabel bebas (indevenden variable), dan variabel $\mathrm{Y}$ : sebagai dimensi dari variabel terikat (devenden variable).

\section{Populasi dan Sampel Penelitian}

Dalam hubungannya dengan penelitian ini, populasi adalah keseluruhan anggota jemaat Gereja Protestan di Indonesia bagian Barat (GPIB) Jemaat Bukit Zaitun Makassar. Dalam penulisan karya ilmiah ini, populasi yang menjadi sampel penelitian adalah warga GPIB Jemaat Bukit Zaitun. Karena jumlah populasi sangat besar yaitu, 1043 kepala keluarga, maka penulis hanya memilih sebagian kecil dari jemaat yaitu, jemaat yang secara aktif terlibat dalam pelayanan. ${ }^{19}$

Teknik yang penulis gunakan ialah, proportionate stratified random sampling ${ }^{20}$ atau sampling acakan secara proporsional menurut stratifikasi. Karena populasi yang dipilih tidak homogen dan berstrata secara proporsional. Unsur yang homogen dari sampel yang penulis pilih adalah aktifis pelayanan gereja yang terdiri dari pemusik, penyanyi, hamba Tuhan, dan jemaat awam.

Tabel 1 Jumlah Sampel

\begin{tabular}{|l|c|c|c|}
\hline \multirow{2}{*}{\multicolumn{1}{|c|}{ Aktifis }} & \multicolumn{2}{|c|}{ Objek } & \multirow{2}{*}{ Jumlah } \\
\cline { 2 - 3 } & Laki-laki & Perempuan & \\
\hline Pendeta Jemaat & 2 & 3 & 5 \\
\hline Majelis/Presbiter & 10 & 5 & 15 \\
\hline Pengiring/Organis & 3 & 2 & 5 \\
\hline Prokantor & 3 & 4 & 7 \\
\hline Pemandu Lagu & 5 & 8 & 13 \\
\hline Paduan Suara & 10 & 15 & 25 \\
\hline $\begin{array}{l}\text { Jemaat } \\
\text { Awam/Senior }\end{array}$ & 10 & 10 & 20 \\
\hline \multicolumn{2}{|l|}{ Total } & 90 \\
\hline
\end{tabular}

\footnotetext{
${ }^{18}$ Ibid., 17.

${ }^{19}$ Komisi Litbang GPIB Jemaat Bukit Zaitun Makassar.

${ }^{20}$ S. Nasution, 87.
} 
Hasil Iterasi Ortogonal I Instrumen Kualitas Ibadah di Gereja Protestan di Indonesia bagian Barat (GPIB) Jemaat Bukit Zaitun Makassar (Variabel Y)

Hasil penghitungan Iterasi ortogonal I (pertama) ${ }^{21}$ untuk variabel Y (Kualitas Ibadah di Gereja Protestan Indonesia bagian Barat Jemaat Bukit Zaitun Makassar) menunjukkan bahwa dari 20 butir instrumen setelah uji coba diperoleh 15 butir valid, ${ }^{22}$ dan 5 butir drop. Dengan demikian dilakukan Iterasi Ortogonal II.

Hasil Iterasi Ortogonal II Instrumen Kualitas Ibadah di Gereja Protestan di Indonesia bagian Barat (GPIB) Jemaat Bukit Zaitun Makassar (Variabel Y)

Hasil penghitungan Iterasi Ortogonal II (kedua) untuk variabel Y (Kualitas Ibadah) di atas menunjukkan bahwa dari 15 butir instrumen setelah uji coba tidak diperoleh butir drop, dan 15 butir dinyatakan valid. Selanjutnya hasil kalibrasi menunjukkan bahwa dari 20 butir instrumen variabel Y, setelah dilakukan dua kali Iterasi Ortogonal, menghasilkan sebanyak 15 butir sebagai instrumen valid untuk diedarkan ke sampel penelitian. Hasil kalibrasi dari 15 butir instrumen variabel Y (Kualitas Ibadah di Gereja Protestan Indonesia bagian Barat Jemaat Bukit Zaitun Makassar) dapat dilihat di bawah ini.

Kalibrasi instrumen (Y),Kualitas Ibadah di Gereja Protestan diIndonesia bagian Barat (GPIB) Jemaat Bukit Zaitun Makassar

Hasilnya menjelaskan bahwa dari 20 butir instrumen yang direncanakan, setelah dilakukan dua kali Iterasi Ortogonal pada taraf signifikansi 0,05 ditetapkan $\mathrm{r}_{\text {kriteria }}$ sebesar 0,361 , ternyata yang valid sebanyak 15 butir, dan yang drop sebanyak 5 butir. ${ }^{23}$

Hal tersebut berarti peneliti tidak memerlukan perangkat lain yaitu factor analysis dengan principle component axis dan iterasi varimax untuk menemukan validasi konstruksi instrumen. Dengan demikian peneliti telah mendapatkan butir-butir instrumen angket untuk dipergunakan dalam penelitian lapangan (sampel). Adapun koefisien reliabilitas instrumen dalam melihat konsistensi jawaban yang diberikan kepada warga Gereja Protestan Indonesia bagian Barat Jemaat Bukit Zaitun, dianalisis dengan menggunakan koefisiensi Alpha Cronbach.

\footnotetext{
${ }^{2 l}$ Penghitungan Uji Validitas Variabel Y (Ortogonal I).

${ }^{22}$ Berdasarkan Bahasa Indonesia, "valid" berarti menurut cara yg semestinya; berlaku; sahih, sesuai dengan teori dan perhitungan.

${ }^{23}$ Penghitungan Uji Validitas Variabel Y (Ortogonal II).
} 
Koefisiensi relibilitas variabel $\mathrm{Y}$ dengan jumlah butir valid sebanyak 15 butir, didapatkan indeks reliabilitas sebesar 0,941. Nilai $\mathrm{r}_{\text {tabel }}$ untuk uji dua sisi pada taraf signifikansi 95\% dengan jumlah responden 30 dan $\mathrm{df}=\mathrm{N}-2=28$ diperoleh angka 0,374. Karena nilai Cronbach's Alpha > dari $\mathrm{r}_{\text {tabel }}$ maka disimpulkan bahwa konstruk pernyataan dari variabel $\mathrm{X}$ terbukti reliabel. ${ }^{24}$

\section{Instrumen Final}

Berdasarkan kalibrasi di atas, maka instrumen final untuk sampel yang akan mengukur variabel Y (Kualitas Ibadah di Gereja Protestan Indonesia bagian Barat Jemaat Bukit Zaitun Makassar) memiliki 15 butir dengan indek keajegan dalam mengukur 0,941. Nilai Cronbach's Alpha berada di antara 0,9 hingga 1, sehingga tingkat reliabilitasnya adalah sangat reliabel. ${ }^{25}$

\section{Teknik Analisis Data}

Data yang diperoleh dari hasil penelitian dianalisis dengan prosedur dan teknik statistik. Pengolahan data dilakukan dengan bantuan program Statistical Product and Service Solution (SPSS) versi 20.

\section{Analisis Deskriptif}

Analisis statistika deskriptif digunakan untuk mendeskripsikan ciri-ciri variabel yang diteliti, yaitu mengetahui harga skor minimum, skor maksimum, rentang (range), rerata (mean), tengah (median), frekuensi terbanyak (modus), standar deviasi, dan varian dari masingmasing variabel penelitian. ${ }^{26}$ Selanjutnya hasil perhitungan tersebut dideskripsikan dalam daftar frekuensi masing-masing variabel yang kemudian divisualkan dalam bentuk histogram.

\section{Uji Persyaratan Analisis}

Uji persyaratan analisis dilakukan untuk memenuhi persyaratan melakukan uji hipokarya ilmiah, yang meliputi:

Pertama, Uji Normalitas. Uji persyaratan analisis yang digunakan dalam penelitian ini adalah uji normalitas data, yaitu untuk mengetahui apakah populasi data berdistribusi normal atau tidak. ${ }^{27}$ Pengujian dengan menggunakan rumus Blom meliputi P-P Plot dengan signifikansi 0,05. Pengujian dilakukan dengan bantuan SPSS 20.

\footnotetext{
${ }^{24}$ Kamus Bahasa Indonesia, "reliabel" artinya hasilnya sama atau dapat dipercaya.

${ }^{25}$ Priyatno, 98

${ }^{26}$ Priyatno, 12.

27 Ibid., 71
} 
Kedua, Uji Linearitas. Linearitas juga merupakan salah satu syarat untuk pengujian dengan menggunakan statistika parametrik, korelasi atau regresi linear. Pengujian ini dilakukan untuk mengetahui apakah dua variabel mempunyai hubungan yang linear atau tidak secara signifikan. ${ }^{28}$ Dalam hal ini uji linearitas menggunakan uji $F$ atau ANOVA. Uji ini untuk melihat apakah persamaan regresi yang dihasilkan linear atau tidak. Dalam pengujian parametrik mensyaratkan bahwa regresi yang dihasilkan harus linear. Pengujian dilakukan dengan bantuan SPSS 20 melalui tes of linearity pada taraf signifikansi 0,05. Dua variabel dikatakan mempunyai hubungan yang linear bila signifikansi (linearity) kurang dari 0,05.

\section{Uji Hipokarya ilmiah}

Uji hipokarya ilmiah adalah pengujian yang bertujuan untuk mengetahui apakah kesimpulan pada sampel dapat berlaku untuk populasi (dapat digeneralasisi). ${ }^{29}$ Uji hipokarya ilmiah yang ditetapkan dalam penelitian ini adalah sebagai berikut: (a) Analisis Koefisiensi Regresi Secara bersama-sama (Uji F), untuk menguji hipokarya ilmiah pertama: Pengaruh Nyanyian Jemaat berpengaruh signifikan terhadap kualitas ibadah di Gereja Protestan Indonesia bagian Barat Jemaat Bukit Zaitun Makassar. (b) Untuk menguji hipokarya ilmiah kedua: menghadap Tuhan adalah faktor yang dominan memengaruhi kualitas ibadah di Gereja Protestan Indonesia bagian Barat Jemaat Bukit Zaitun Makassar, dengan menggunakan: uji determinasi varians $\left(\mathrm{r}_{\text {yn }}^{2}\right.$ ) (untuk mengetahui porsentase sumbangan pengaruh $\mathrm{X}_{1}, \mathrm{X}_{2}, \mathrm{X}_{3}, \mathrm{X}_{4}$, terhadap $\mathrm{Y}$ ). (c) Uji koefisiensi regresi secara bersama-sama (Uji $F$ ). Uji ini digunakan untuk mengetahui apakah variabel independen $\left(\mathrm{X}_{1}, \mathrm{X}_{2}, \ldots \mathrm{X}_{4}\right)$ secara bersama-sama berpengaruh secara signifikan terhadap variabel dependen (Y).

Dalam penelitian ini dilakukan dengan menjelaskan rumusan hipokarya ilmiah, menentukan tingkat signifikansi dengan menggunakan tingkat signifikansi 0,05 ( $\alpha=5 \%)$, menentukan F hitung, menentukan $\mathrm{F}$ tabel, kriteria pengujian, membandingkan $\mathrm{F}$ hitung dengan F tabel, mengamati gambar hasil hitung, lalu memberikan kesimpulan. Adapun langkah-langkah pengujiannya sebagai berikut:

Pertama, menentukan hipokarya ilmiah. Dalam hal ini akan ditentukan Ho dan Ha, yaitu: Ho: artinya tidak ada pengaruh antara nyanyian jemaat terhadap kualitas ibadah di Gereja Protestan Indonesia bagian Barat Jemaat Bukit Zaitun Makassar. Ha: artinya ada pengaruh antara nyanyian jemaat dengan kualitas ibadah di Gereja Protestan

\footnotetext{
${ }^{28}$ Ibid. 73

${ }^{29}$ Ibid., 9.
} 
Indonesia bagian Barat Jemaat Bukit Zaitun Makassar. Kedua, menentukan tingkat signifikansi. Dalam penelitian ini digunakan tingkat signifikansi 0,05. Ketiga, menentukan F hitung. Berdasarkan output yang akan diperoleh. Keempat, menentukan F tabel. Dengan menggunakan tingkat keyakinan 95\%, $\alpha=5 \%$, dengan derajat kebebasan df 1 (jumlah variabel-1) atau $\mathrm{n}-\mathrm{k}-1$ atau 370-11-1=358 (n adalah jumlah kasus dan $\mathrm{k}$ adalah jumlah variabel independen). Kemudian lihat $\mathrm{F}$ tabel. Kelima, kriteria pengujian: $\mathrm{H}_{0}$ diterima jika $\mathrm{F}_{\text {hitung }}<\mathrm{F}_{\text {tabel }}$ dan $\mathrm{H}_{0}$ ditolak jika $F_{\text {hitung }}>F_{\text {tabel }}$. Keenam, membandingkan $F$ hitung dengan $F$ tabel. Ketujuh, menarik kesimpulan ada tidaknya Pengaruh Nyanyian Jemaat terhadap Kualitas Ibadah di Gereja Protestan Indonesia bagian Barat Jemaat Bukit Zaitun Makassar. 


\section{HASIL PENELITIAN DAN PEMBAHASAN}

\section{Deskripsi Data}

Hasil penelitian lapangan diuraikan dalam deskripsi data berikut ini. Deskripsi data yang disajikan adalah masing-masing indikator dari variabel pengaruh nyanyian jemaat (X). Di samping itu disajikan pula hasil analisis penelitian dari variabel kualitas ibadah di Gereja Protestan di Indonesia bagian Barat Jemaat Bukit Zaitun Makassar (Y).

\section{Deskripsi Data Variabel Pengaruh Nyanyian Jemaat (X)}

Berdasarkan data sampel (n) sebesar 90 tabulasi data, ditemukan Mean 69,82; Median 72,00; Mode 76; Standart Deviation 6,445; Range 26; Minimum 50; Maximum 76. Output SPSS untuk statistik deskriptif tersebut, tabelnya seperti di bawah ini:

\section{Statistics}

$\mathrm{X}=$ Nyanyian Jemaat

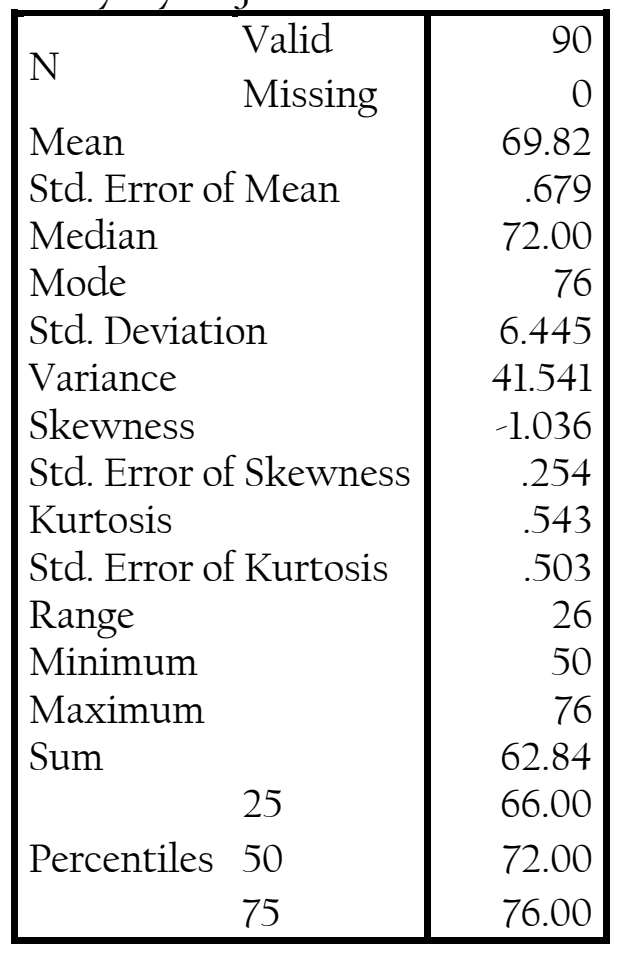


Analisis data deskriptif pengaruh nyanyian jemaat di atas dapat dilihat dalam bentuk histogram sebagai berikut:

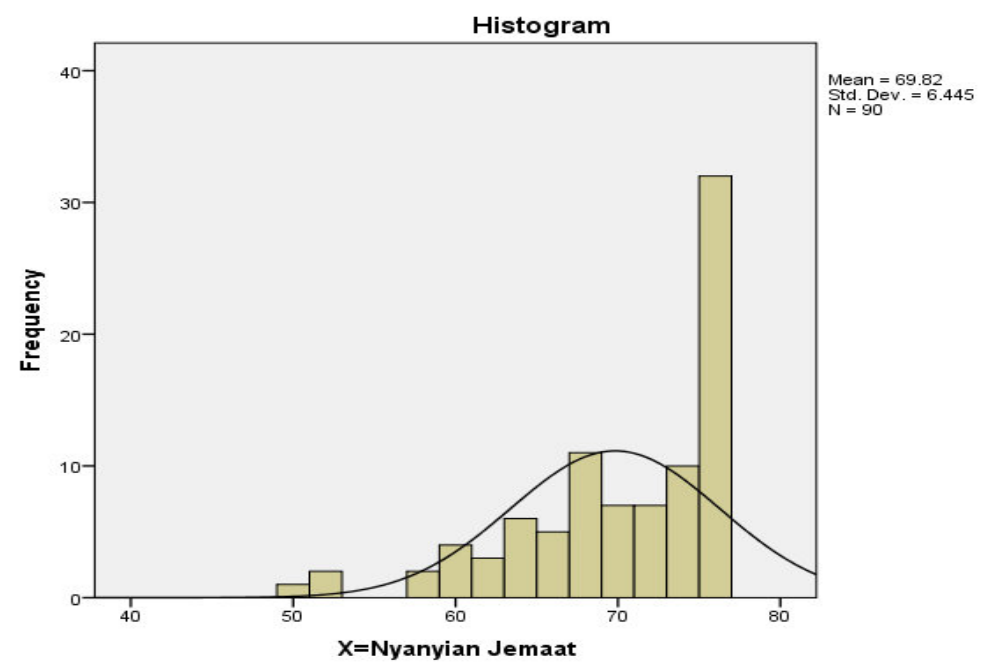

Berdasarkan tabel statistik di atas, maka dalam histogram di atas terlihat kecenderungan ke kanan. Hal ini terjadi karena nilai skewnees negative $(-0,036)$, sedangkan nilai kurtosis positif $(0,543)$. Jadi dapat diinterpretasikan bahwa histogram memiliki ketidakseimbangan dalam arah hubungan $\mathrm{X}$ terhadap $\mathrm{Y}$.

Deskripsi Data Kualitas Ibadah di Gereja Protestan di Indonesia bagian Barat Jemaat Bukit Zaitun Makassar (Y)

Berdasarkan data sampel (n) sebesar 90 tabulasi data, ditemukan Mean 29,43; Median 27,00; Mode 20; Standart Deviation 9,641; Range 39; Minimum 17; Maximum 56. Tabelnya seperti di bawah ini:

\section{Statistics}

\begin{tabular}{|c|c|c|}
\hline \multicolumn{3}{|c|}{ Y=Kualitas Ibadah } \\
\hline & Valid & 90 \\
\hline & Missing & 0 \\
\hline $\mathrm{Me}$ & & 29.43 \\
\hline Std & f Mean & 1.016 \\
\hline $\mathrm{Me}$ & & 27.00 \\
\hline Mo & & $20^{a}$ \\
\hline Std & & 9.641 \\
\hline Var & & 92.945 \\
\hline Ske & & .838 \\
\hline
\end{tabular}




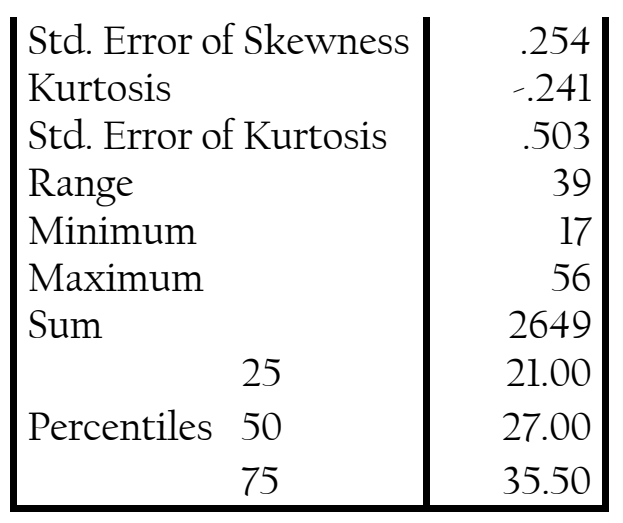

a. Multiple modes exist. The smallest value is shown

Analisis data deskriptif kualitas ibadah di atas dapat dilihat dalam histogram sebagai berikut:

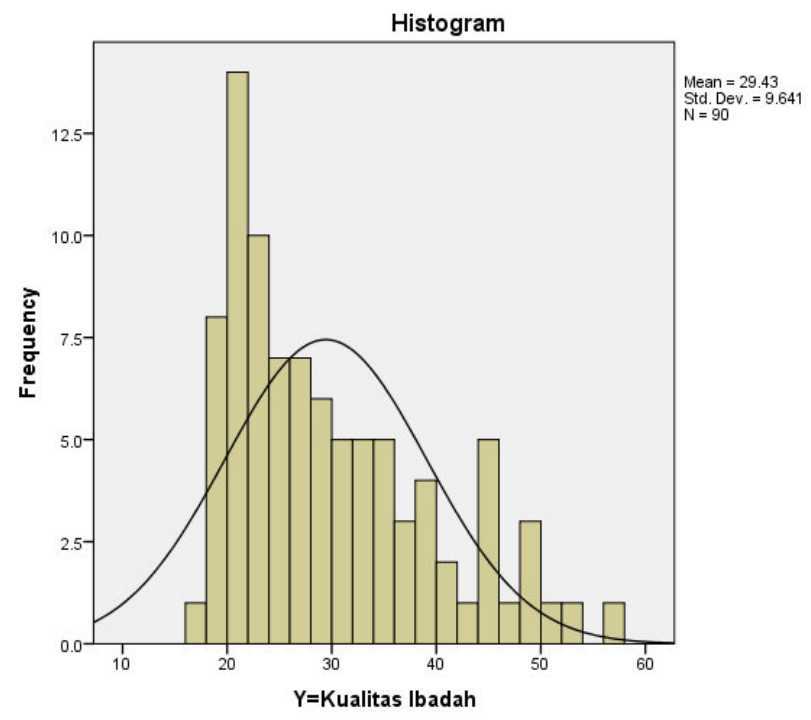

Selanjutnya berdasarkan Ostatistik di atas, maka dalam histogram terlihat kecenderungan ke kiri. Hal ini terjadi karena nilai skewnees positif $(0,838)$, sedangkan nilai kurtosis negatif $(-0,241)$. Jadi, dapat diinterpretasikan bahwa histogram $\mathrm{Y}$ berbanding terbalik dengan $\mathrm{X}$.

\section{Uji Persyaratan Analisis}

Sebelum melangkah ke uji hipokarya ilmiah penelitian ini, lebih dahulu peneliti akan melakukan uji persyaratan analisis untuk mengetahui apakah masing-masing variabel penelitian ini memenuhi persyaratan. 


\section{Uji Normalitas}

Uji normalitas digunakan untuk menguji kenormalan data. Dalam hal ini apakah data mengikuti distribusi normal atau tidak. Itu diperlukan karena pengujian hipokarya ilmiah dengan statistik parametrik salah satu persyaratannya ialah data berdistribusi normal. ${ }^{30}$ Dalam penelitian ini, pengujian normalitas dilakukan untuk setiap skor variabel/indikator.

Uji normalitas data variabel dan indikator dilakukan dengan estimasi proporsi dari rumus Blom, karena peneliti akan menguji hipokarya ilmiah dengan analisis regresi linear. Hasilnya untuk distribusi data: pengaruh nyanyian jemaat (X) dengan indikator menghadap Tuhan $\left(\mathrm{X}_{1}\right)$, pelayanan Firman $\left(\mathrm{X}_{2}\right)$, pengucapan syukur $\left(X_{3}\right)$, pengutusan $\left(X_{4}\right)$, dan variabel $Y$ yaitu kualitas ibadah adalah memiliki normal plot dan toleransi normal, demikian juga detrended-nya tidak menunjukkan kurva sinus. Dengan demikian distribusi data variabel dan semua indikator pada kategori normal.

\section{Uji Linearitas}

Uji linearitas bertujuan untuk mengetahui apakah dua variabel mempunyai hubungan yang linear atau tidak secara signifikan. Uji ini biasanya digunakan sebagai prasyarat dalam analisis korelasi atau regresi linear. ${ }^{31}$

Uji linearitas dalam penelitian ini dilakukan dengan bantuan SPSS dengan menggunakan Test for Linearity pada taraf signifikansi 0,05. Khusus untuk uji linearitas, dua variabel dikatakan mempunyai hubungan yang linear bila signifikansi pada baris deviation from linearity > dari 0,05 . Jika nilai signifikan pada pada baris deviation from linearity < dari 0,05 maka dilanjutkan dengan uji estimasi kurva.

Uji linearitas dilakukan dengan analisis regresi antara pengaruh nyanyian jemaat dengan kualitas ibadah di Gereja Protestan di Indonesia bagian Barat Jemaat Bukit Zaitun Makassar. Jika dihasilkan F dengan value $(\alpha>0,05)$, artinya hubungan indikator pengaruh nyanyian jemaat $\left(\mathrm{X}_{1}, \mathrm{X}_{2}, \mathrm{X}_{3}, \mathrm{X}_{4}\right)$ terhadap kualitas ibadah adalah linear.

Hasil uji linearitas analisis regresi residu $\mathrm{X}$ terhadap $\mathrm{Y}$, dihasilkan F sebesar 0,952 adalah signifikan pada $\alpha=0,000,(\alpha>0,05)$. Artinya hubungan antara X terhadap Y adalah linear.

\footnotetext{
${ }^{30}$ Priyatno, 71 .

${ }^{31}$ Priyatno, 73.
} 


\section{Uji Hipokarya ilmiah}

Dalam penelitian ini terdapat dua hipokarya ilmiah yang akan diuji, yakni:

Pertama, nyanyian jemaat berpengaruh signifikan terhadap kualitas ibadah di Gereja Protestan di Indonesia bagian Barat Jemaat Bukit Zaitun Makassar.

Kedua, kategori unsur menghadap Tuhan berpengaruh kuat dan dominan terhadap kualitas ibadah di Gereja Protestan di Indonesia bagian Barat Jemaat Bukit Zaitun Makassar.

\section{Uji Hipokarya ilmiah Pertama}

Pada bagian ini dilakukan uji hipokarya ilmiah bahwa nyanyian jemaat berpengaruh signifikan terhadap kualitas ibadah di Gereja Protestan Indonesia bagian Barat Jemaat Bukit Zaitun Makassar. Dalam menentukan tingkat signifikansi dengan menggunakan tingkat signifikansi 0,05 ( $\alpha=5 \%)$, menentukan F hitung, menentukan F tabel, kriteria pengujian, membandingkan $\mathrm{F}$ hitung dengan $\mathrm{F}$ tabel, mengamati gambar hasil hitung, lalu memberikan kesimpulan.

ANOVA $^{\mathrm{a}}$

\begin{tabular}{|l|r|r|r|r|r|}
\hline Model & \multicolumn{1}{|c|}{$\begin{array}{c}\text { Sum of } \\
\text { Squares }\end{array}$} & df & Mean Square & F & \multicolumn{1}{c|}{ Sig. } \\
\hline Regression & 31.421 & 1 & 31.421 & .299 & $.586^{\mathrm{b}}$ \\
$1 \quad$ Residual & 9244.901 & 88 & 105.056 & & \\
\multicolumn{1}{|l}{ Total } & 9276.322 & 89 & & & \\
\hline
\end{tabular}

a. Dependent Variable: Y=Kualitas Ibadah

b. Predictors: (Constant), $\mathrm{X}=$ Nyanyian Jemaat

Hasil analisis menunjukkan bahwa karena $F_{\text {hitung }}<F_{\text {tabel }}$ $(0,299<3,950)$, maka, Ho diterima, artinya nyanyian jemaat tidak berpengaruh terhadap kualitas ibadah di Gereja Protestan di Indonesia bagian Barat Jemaat Bukit Zaitun Makassar. Hal ini berarti kualitas ibadah tidak signifikan dipengaruhi oleh nyanyian jemaat.

Persamaan regresi liner menunjukkan $Y=23,838+0,095 x$. Artinya, setiap pengaruh nyanyian jemaat, maka kualitas ibadah di Gereja Protestan di Indonesia bagian Barat Jemaat Bukit Zaitun Makassar, akan meningkat sebesar 0,095 kali dari sekarang. Jadi pengaruhnya sangat tidak signifikan. Sedang uji regresi menunjukkan F sebesar adalah 0,299 sangat tidak signifikan pada $\alpha<0,05$.

Jadi, hipokarya ilmiah yang menyatakan nyanyian jemaat berpengaruh signifikan terhadap kualitas ibadah di Gereja Protestan di Indonesia bagian Barat Jemaat Bukit Zaitun Makassar adalah tidak terbukti dalam penelitian ini. 


\section{Uji Hipokarya ilmiah Kedua}

Dalam uji hipokarya ilmiah kedua ini, peneliti menggunakan pendekatan yaitu: Determinasi varians $\left(\mathrm{r}_{\text {yn }}^{2}\right)$ (untuk mengetahui persentase sumbangan pengaruh $\mathrm{X}_{1}, \mathrm{X}_{2}, \mathrm{X}_{3}$, dan $\mathrm{X}_{4}$ terhadap $\mathrm{Y}$ ).

Persamaan regresi dari masing-masing indikator variabel $X$ terhadap variabel Y dapat dilihat dalam tabel coefificients sebagai berikut: Coefficients $^{\mathrm{a}}$

\begin{tabular}{|l|r|r|r|r|r|}
\hline \multirow{2}{*}{ Model } & \multicolumn{2}{|c|}{$\begin{array}{c}\text { Unstandardized } \\
\text { Coefficients }\end{array}$} & $\begin{array}{c}\text { Standardized } \\
\text { Coefficients }\end{array}$ & \multicolumn{1}{c|}{ Sig. } & \\
\cline { 2 - 4 } & \multicolumn{1}{|c|}{$\mathrm{B}$} & Std. Error & \multicolumn{1}{|c|}{ Beta } & & \\
\hline (Constant) & 25.509 & 15.322 & & 1.665 & .100 \\
Xl=Menghadap Tuhan & -.614 & 1.362 & -.064 & -.451 & .653 \\
X2=Pelayanan Firman & -1.019 & .934 & -.204 & -1.091 & .278 \\
X3=Pengucapan Syukur & 2.329 & .980 & .436 & 2.376 & .020 \\
X4=Pengutusan & -.559 & .834 & -.113 & -.671 & .504 \\
\hline
\end{tabular}

a. Dependent Variable: Y=Kualitas Ibadah

Konstanta sebesar 25.509 artinya jika menghadap Tuhan $\left(\mathrm{X}_{1}\right)$, pelayanan Firman $\left(\mathrm{X}_{2}\right)$, pengucapan syukur $\left(\mathrm{X}_{3}\right)$, pengutusan $\left(\mathrm{X}_{4}\right)$ adalah 0, maka kualitas ibadah di Gereja Protestan di Indonesia bagian Barat Jemaat Bukit Zaitun Makassar nilainya adalah 25.509. Adapun seluruh persamaan regresi di atas dapat dijelaskan sebagai berikut:

Pertama, Koefisiensi regresi variabel menghadap Tuhan $\left(\mathrm{X}_{1}\right)$ sebesar $-0,614$; artinya jika menghadap Tuhan mengalami kenaikan $1 \%$, kualitas ibadah di Gereja Protestan di Indonesian bagian Barat Jemaat Bukit Zaitun Makassar (Y) akan mengalami penurunan sebesar 0,614 dengan asumsi variabel indipenden lainnya tetap.

Koefisiensi bernilai negatif artinya terjadi hubungan negatif antara menghadap Tuhan dengan kualitas ibadah di Gereja Protestan Indonesia bagian Barat Jemaat Bukit Zaitun Makassar. Adapun hubungan menghadap Tuhan $\left(\mathrm{X}_{1}\right)$ dengan $\mathrm{Y}$ dihasilkan ry ${ }_{1}$ sebesar 0,034 dan adjusted R Square sebesar -0,010. Artinya, hubungan pengaruh $\mathrm{X}_{1}$ dengan Y negatif.

Kedua, koefisiensi regresi variabel pelayanan Firman $\left(\mathrm{X}_{2}\right)$ sebesar 1,019; artinya jika pelayanan Firman mengalami kenaikan 1\%, maka kualitas ibadah (Y) akan mengalami penurunan sebesar 1,019 dengan asumsi variabel indipenden lainnya tetap.

Koefisiensi bernilai sangat negatif artinya terjadi hubungan negatif antara pelayanan Firman dengan kualitas ibadah di Gereja Protestan di Indonesia bagian Barat Jemaat Bukit Zaitun Makassar. Adapun hubungan pelayanan Firman $\left(\mathrm{X}_{2}\right)$ dengan Y dihasilkan ry2 sebesar 0,009 dan adjusted $R$ Square sebesar -0,01l. Artinya, hubungan pengaruh $\mathrm{X}_{2}$ dengan $Y$ adalah negatif. 
Ketiga, koefisiensi regresi variabel pengucapan syukur $\left(\mathrm{X}_{3}\right)$ sebesar 2,329; artinya jika pengucapan syukur mengalami kenaikan $1 \%$, maka kualitas ibadah Gereja Protestan di Indonesia bagian Barat Jemaat Bukit Zaitun Makassar (Y) akan mengalami kenaikan sebesar 2,329 dengan asumsi variabel indipenden lainnya tetap. Koefisiensi bernilai positif artinya terjadi hubungan positif antara pengucapan syukur dengan kualitas ibadah di GPIB Jemaat Bukit Zaitun Makassar. Semakin naik frekuensi pengucapan syukur (respon), maka semakin naik pula kualitas ibadah di GPIB Jemaat Bukit Zaitun Makassar. Adapun hubungan pengucapan syukur $\left(\mathrm{X}_{3}\right)$ dengan $\mathrm{Y}$ dihasilkan ry $_{3}$ sebesar 0,157 dan adjusted $\mathrm{R}$ Square sebesar 0,013. Artinya, hubungan pengaruh $\mathrm{X}_{3}$ dengan $\mathrm{Y}$ sebesar 1,3\%. Keempat, koefisiensi regresi variabel pengutusan $\left(\mathrm{X}_{4}\right)$ sebesar -0,559, artinya jika pengutusa mengalami kenaikan $1 \%$, maka kualitas ibadah di GPIB Jemaat Bukit Zaitun Makassar (Y) akan mengalami penurunan sebesar 0,559 dengan asumsi variabel indipenden lainnya tetap. Koefisiensi bernilai negatif artinya terjadi hubungan negatif antara pengutusan dengan kualitas ibadah di GPIB Jemaat Bukit Zaitun Makassar. Adapun hubungan pengutusan $\left(\mathrm{X}_{4}\right)$ dengan $\mathrm{Y}$ dihasilkan ry 4 sebesar 0,004 dan adjusted R Square sebesar -0,01l. Artinya, hubungan pengaruh $\mathrm{X}_{4}$ dengan $\mathrm{Y}$ sebesar $-1,1 \%$.

Jadi, hipokarya ilmiah yang mengatakan bahwa variabel menghadap Tuhan adalah faktor yang dominan memengaruhi kualitas ibadah di GPIB Jemaat Bukit Zaitun Makassar, ditolak. Porsentase sumbangan $\mathrm{X}_{1}, \mathrm{X}_{2}, \mathrm{X}_{3}$, dan $\mathrm{X}_{4}$ menunjukkan bahwa pengucapan syukur $\left(X_{3}\right)$ satu-satunya variabel yang berpengruh positif dari variabel lainnya terhadap kualitas ibadah di Gereja Protestan Indonesia bagian Barat Jemaat Bukit Zaitun Makassar. Sedangkan variabel lainnya: $X_{1}, X_{2}$, dan $\mathrm{X}_{4}$ berpengaruh negatif terhadap $\mathrm{Y}$. 


\section{PENUTUP}

\section{Kesimpulan}

Berdasarkan hasil pengolahan data yang diperoleh, peneliti dapat menarik kesimpulan bahwa:

Pertama, hipokarya ilmiah yang menyatakan nyanyian jemaat berpengaruh signifikan terhadap kualitas ibadah di Gereja Protestan Indonesia bagian Barat Jemaat Bukit Zaitun Makassar adalah tidak terbukti dalam penelitian ini. Hasil analisis menunjukkan $F_{\text {hitung }}<\mathrm{F}_{\text {tabel }}$ $(0,299<3,950)$, maka Ho diterima, artinya nyanyian jemaat tidak berpengaruh terhadap kualitas ibadah di Gereja Protestan di Indonesia bagian Barat Jemaat Bukit Zaitun Makassar. Hal ini berarti kualitas ibadah tidak signifikan dipengaruhi oleh nyanyian jemaat.

Kedua, hipokarya ilmiah yang mengatakan bahwa variabel menghadap Tuhan adalah unsur yang dominan memengaruhi kualitas ibadah di GPIB Jemaat Bukit Zaitun Makassar, ditolak. Porsentase sumbangan $X_{1}, X_{2}, X_{3}$, dan $X_{4}$ menunjukkan bahwa pengucapan syukur $\left(\mathrm{X}_{3}\right)$ satu-satunya variabel yang berpengaruh positif dari variabel lainnya terhadap kualitas ibadah di Gereja Protestan di Indonesia bagian Barat Jemaat Bukit Zaitun Makassar.

Adapun koefisiensi regresi variabel pengucapan syukur $\left(\mathrm{X}_{3}\right)$ sebesar 2,329; artinya jika pengucapan syukur mengalami kenaikan $1 \%$, maka kualitas ibadah GPIB Jemaat Bukit Zaitun Makassar (Y) akan mengalami kenaikan sebesar 2,329 dengan asumsi variabel indipenden lainnya tetap. Koefisiensi bernilai positif artinya terjadi hubungan positif antara pengucapan syukur dengan kualitas ibadah di GPIB Jemaat Bukit Zaitun Makassar. Semakin naik frekuensi pengucapan syukur (respon), maka semakin naik pula kualitas ibadah di GPIB Jemaat Bukit Zaitun Makassar. Adapun hubungan pengucapan syukur $\left(\mathrm{X}_{3}\right)$ dengan $\mathrm{Y}$ dihasilkan ry 3 sebesar 0,157 dan adjusted R Square sebesar 0,013. Artinya, hubungan pengaruh $\mathrm{X}_{3}$ dengan $\mathrm{Y}$ sebesar 1,3\%. Koefisiensi regresi variabel menghadap Tuhan $\left(\mathrm{X}_{1}\right)$ sebesar $-0,614$; artinya jika menghadap Tuhan mengalami kenaikan 1\%, kualitas ibadah di GPIB Bukit Zaitun Makassar (Y) akan mengalami penurunan sebesar 0,614 dengan asumsi variabel indipenden lainnya tetap.

Koefisiensi bernilai negatif artinya terjadi hubungan negatif antara menghadap Tuhan dengan kualitas ibadah di Gereja Protestan Indonesia bagian Barat Jemaat Bukit Zaitun Makassar. Adapun hubungan

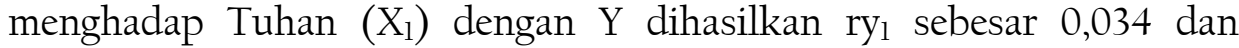
adjusted $\mathrm{R}$ Square sebesar -0,010. Artinya, hubungan pengaruh $\mathrm{X}_{1}$ dengan $\mathrm{Y}$ negatif. Koefisiensi regresi variabel pelayanan Firman $\left(\mathrm{X}_{2}\right)$ sebesar -1,019; artinya jika pelayanan Firman mengalami kenaikan 1\%, 
maka kualitas ibadah (Y) akan mengalami penurunan sebesar 1,019 dengan asumsi variabel independen lainnya tetap. Koefisiensi bernilai sangat negatif artinya terjadi hubungan negatif antara pelayanan Firman dengan kualitas ibadah di Gereja Protestan di Indonesia bagian Barat Jemaat Bukit Zaitun Makassar. Adapun hubungan pelayanan Firman $\left(\mathrm{X}_{2}\right)$ dengan $\mathrm{Y}$ dihasilkan ry 2 sebesar 0,009 dan adjusted R Square sebesar 0,011 . Artinya, hubungan pengaruh $\mathrm{X}_{2}$ dengan $\mathrm{Y}$ adalah negatif. Koefisiensi regresi variabel pengutusan $\left(\mathrm{X}_{4}\right)$ sebesar $-0,559$, artinya jika pengutusa mengalami kenaikan $1 \%$, maka kualitas ibadah di GPIB Jemaat Bukit Zaitun Makassar (Y) akan mengalami penurunan sebesar 0,559 dengan asumsi variabel independen lainnya tetap. Koefisiensi bernilai negatif artinya terjadi hubungan negatif antara pengutusan dengan kualitas ibadah di GPIB Jemaat Bukit Zaitun Makassar. Adapun hubungan pengutusan $\left(\mathrm{X}_{4}\right)$ dengan $\mathrm{Y}$ dihasilkan ry ${ }_{4}$ sebesar 0,004 dan adjusted $\mathrm{R}$ Square sebesar $-0,01$. Artinya, hubungan pengaruh $\mathrm{X}_{4}$ dengan $\mathrm{Y}$ sebesar $-1,1 \%$. 


\section{KEPUSTAKAAN}

Alkitab

Alkitab. Terjemahan LAI Jakarta: Lembaga Alkitab Indonesia, 2005.

Alkitab. Edisi Studi. Lembaga Alkitab Indonesia, 2010.

Kamus

Wojowasito, S. Kamus Umum Bahasa Indonesia. Malang: CV Pengarang, 2011.

Buku-Buku

Abineno, J.L.CH. Unsur Unsur Liturgia yang dipakai oleh Gereja-Gereja di Indonesia. Jakarta: Penerbit BPK Gunung Mulia, 2005.

Appleby, David P. History of Church Music. Chicago: Moody Press, 1965

Boschman, Lamar. Exploring The Mysteries of Worship. Yogyakarta: PT ANDI, 2009.

Campbell, Don. Efek Mozart. Jakarta: Gramedia Pustaka, 2001.

Carson, D.A. Worship by the Book. Grand Rapids, Michigan USA:

Zordervan, 2002.

Worship Adoration And Action. Eugene, Oregon: Wipf and Stock Publishers, 2002.

Eliezer, Sasmoko. Metode Penelitian, Pengukuran dan Analisis Data. Tangerang: Harvest Internasional Theological Seminary, 2005.

Fred N. dan Howard B. Lee. Foundations of Behavioral Research. Forth Worth: Harcout College Publisher, 2000.

Hagin Jr, Kenneth. The Untapped Power In Praise. Jakarta: Metanoia Publishing, 1990 .

Hale, Leonard. Jujur Terhadap Pietisme. Jakarta: BPK Gunung Mulia, 1996.

Handojo, Djohan E. The Fire of Praise and Worship. Yogyakarta: Andi, 2010.

IIesch Barry. The New Worship. Michigan: Barker Book, 2008.

Jonge, de.Christiaan. Apa Itu Calvinisme. Jakarta: BPK Gunung Mulia, 2011.

Lahagu, Faoziduhu. Ibadah Sebagai Gaya Hidup. Yogyakarta: Andi, 2012.

Martasudjita, E.Pr-Kristanto, J.Pr. Musik \& Nyanyian Liturgi. Yogyakarta: Penerbit Kanisius, 2000.

Rachman, Rasid. Hari Raya Liturgi. Jakarta: Penerbit BPK Gunung Mulia, 2003

Pembimbing Ke Dalam Sejarah Liturgi. Jakarta: BPK Gunung Mulia, 2010 
Redman, Matt. Menyembah Dalam Roh Dan Kebenaran. Yogyakarta: Andi, 2003

Sugiyono. Statistika untuk Penelitian. Bandung: Alfabeta, 1999.

Sugiyono. Metode Penelitian Administrasi. Bandung: Alfabeta, 2005.

Sumadi, Suryabrata. Metodologi Penelitian. Jakarta: PT. Raja Grafindo Persada, 2006

White, F James. Pengantar Ibadah Kristen. Jakarta:BPK Gunung Mulia, 2012

Zschech, Darlene. Extravagant Worship. Jakarta: Immanuel, 2006.

E. Martasudjita Pr, Penyajian Musik Gereja Dalam Perayaan Liturgi Musik Gereja Zaman Sekarang (Yogyakarta: PML A-63, 2009), 